\title{
Hepatoprotective Potentials Of Hibiscus Rosasinensis Petal anthocyanin Extracts Against Carbon tetrachloride-Induced Acute Liver Damage in Wistar Rats.
}

Onyesom I*. Mordi J. Opajobi AO. and ${ }^{\mathrm{a} E s u m e ~ C O . ~}$

\begin{abstract}
Carbon tetrachloride $\left(\mathrm{CCl}_{4}\right)$ is haloalkane that possesses a hepatotoxic effect.

Material and Methods: The impact of anthocyanin fractions obtained from Hibiscus rosasinensis petal on carbon tetrachloride $\left(\mathrm{CCl}_{4}\right)$ - induced acute liver damage in wistar rats was studied using a combination of alanine transferase (ALT) activity value and liver: body weight gain ratio as indices.

Results: $\mathrm{CCl}_{4}$ treatment significantly increased both ALT value and the liver: body weight gain ratio at the $1 \%$ probability level when compared with the control values.

Conclusion: Pre-treatment with the anthocyanin fractions reduced the levels of these markers and hence, the degree of liver damage, though with varying potentials. The lead precipitated, non - slimy red fraction possessed the greatest protective property on the rat liver when compared with the other anthocyanin fractions so tested.
\end{abstract}

KEY WORDS: Anthocyanin, carbon tetrachloride, alanine transferase, Hibiscus rosasinensis, liver damage.

$\mathrm{C}$ arbon tetrachloride $\left(\mathrm{CCl}_{4}\right)$ is haloalkane that possesses a hepatotoxic effect. The hepatotoxicity has been extensively studied and its proposed mechanism involves initial reductive dechlorination of carbon tetrachloride $\left(\mathrm{CCl}_{4}\right)$ to trichloromethyl radical $\left({ }^{\circ} \mathrm{CCl}_{3}\right)$ which subsequently precipitate membrane lipid peroxidation and hence liver damage ${ }^{1}$. Investigations have demonstrated that the liver injury produced by $\mathrm{CCl}_{4}$ could be prevented or greatly modified by pre-treating animals with various antioxidants ${ }^{2}$.

Anthocyanin, a water-soluble glycoside of anthocyanidins, is a plant pigment. They are part of the $\mathrm{C} 15$ phenolics known collectively as flavonoids with the typical A-ring benzoyl and B-ring hydroxycinnamoyl system.

* . Department of Medical Biochemistry,

a . Department of Pharmacology

Delta State University, Abraka, Nigeria.
Anthocyanins are used in industries mostly as colourants and flavour enhancers. However, they serve protective functions in plants, hence speculated to have antioxidant properties $^{3}$. This tendency may be due to their phenolic structure which shows antioxidant activity towards a variety of easily oxidizable substances and might be part of anthocyanin defense mechanisms against free radical mediated damage ${ }^{4}$.

This study reports the protective capacities of partially purified extracts of $H$. rosasinensis petal anthocyanin against carbon tetrachloride-induced liver damage.

\section{Materials and Methods}

Animals: Forty-nine (49) adult albino rats (Wistar strain) with an initial mean weight of $154 \pm 16 \mathrm{~g}(135-170 \mathrm{~g})$ were used for the study. The rats were obtained from the Animal Unit, Faculty of Pharmacy, University of Benin, Benin City, Edo State, Nigeria.

Collection of Hibiscus Flowers: Hibiscus flowers (Hibiscus rosasinensis) were collected from the environment in University of Benin, Ugbowo, Benin City. 
Extraction and Purification of Anthocyanins: Anthocyanins were extracted from flower petals and purified as previously described ${ }^{5}$. The extracts obtained from the stepwise purification techniques were respectively labelled: $\mathrm{AN}_{1}, \mathrm{AN}_{2}, \mathrm{AN}_{3}, \mathrm{AN}_{4}$ and $\mathrm{AN}_{5}$. $\mathrm{AN}_{1}$ is the crude anthocyanin extract and $\mathrm{AN}_{2}$, the lead precipitated extract, while $\mathrm{AN}_{3}$ is the 12 x $3.5 \mathrm{~cm}$ sephadex G-50 column fraction. $\mathrm{AN}_{4}$ and $\mathrm{AN}_{5}$ are $50 \times 10 \mathrm{~cm}$ sephadex $\mathrm{G}-50$ column fractions 1 and 2, respectively. $\mathrm{AN}_{2}$ was obtained from crude, while the column fractions were obtained from $\mathrm{AN}_{2}$.

Treatment of animals and anthocyanin adminstration:

The rats were allowed to acclimatize to the feed and laboratory condition for 7 days. Thereafter, they were divided into seven experimental groups with seven rats each. They were provided with feed (rat pellets) and clean water ad libitum.

Rats in groups 1 and 2 were given $0.25 \mathrm{ml}(5 \%)$ ethanol $/ 100 \mathrm{~g}$ body weight, 5 days a week for four (4) weeks. Rats in groups 3,4,5,6 and 7 received a solution of $\mathrm{AN}_{1}, \mathrm{AN}_{2}, \mathrm{AN}_{3}, \mathrm{AN}_{4}$ and $\mathrm{AN}_{5}$ extracts respectively, in $5 \%$ ethanol $(1: 1 \mathrm{v} / \mathrm{v})$ at a dose of $0.25 \mathrm{ml} / 100 \mathrm{~g}$ body weight. All administrations were given orally by intubation.

Administration of Carbon Tetrachloide $\left(\mathrm{CCl}_{4}\right)$ :

After the 4 - week anthocyanin treatment period, the rats in groups 2, 3, 4, 5, 6 and 7 received $0.6 \mathrm{ml} \mathrm{CCl}_{4}$ (in corn oil, $1: 1 \mathrm{v} / \mathrm{v}$ ) per $100 \mathrm{~g}$ body weight by subcutaneous injection after a 12-hour fast. The animals were then sacrificed after 18 hours of the $\mathrm{CCl}_{4}$ treatment. The dosing regimen and the administration method were based on previous experience ${ }^{6}$.

\section{Collection of Blood and Liver Samples:}

Each rat was anaesthetised in chloroform saturated chamber and the abdominal and thoracic regions were surgically opened to expose the liver and the heart. Whole blood sample was then collected from the heart using $5 \mathrm{ml}$ hypodermic syringe and needle into lithium heparinized sample bottle. After leaving to stand on ice for few minutes, the sample was centrifuged at $1200 \mathrm{x}$ g for about $5 \mathrm{~min}$ at room temperature in order to separate the plasma which was collected and stored frozen in bijou bottle. Analysis was done within 48 hours of collection. The liver was also excised, washed and weighed fresh.

Analysis of specimens:

Plasma Alanine transferase (ALT) activity value was determined by a colorimetric $\operatorname{method}^{7}$, using commercially available reagent test kit supplied by Quimica Clinica Aplicada, S.A., Spain.

\section{Statistics:}

Analysis of variance (ANOVA) was used to compare group values, followed by NewmanKeuls post-hoc test ${ }^{8}$ to determine statistical significance between the groups. Differences were considered significant when $\mathrm{P}<0.05$.

\section{Results:}

The results obtained from the study were shown on Tables 1 and 2. Table 1 presents the changes in plasma alanine transferase (ALT) activity values for the various experimental groups. From Table 1, it can be observed that carbontetrachloride $\left(\mathrm{CCL}_{4}\right)$ treatment significantly $(\mathrm{P}<0.01)$ increased ALT activity value by over $700 \%$ when compared with the control value. 
Table 1: Changes in mean plasma alanine transferase (ALT) activity values for the different experimental groups.

\begin{tabular}{lllll}
\hline Group & Treatment & $\begin{array}{l}\text { ALT Activity } \\
\text { (IU/L) }\end{array}$ & $\begin{array}{l}\text { Percentage mean } \\
\text { increase } \\
\text { compared with G1 }\end{array}$ & $\begin{array}{l}\text { Percentage mean } \\
\text { decrease } \\
\text { compared with G2 }\end{array}$ \\
\hline G1 & Control & $61.89 \pm 1.51^{+}$ & - & 88.08 \\
G2 & $\mathrm{CCl}_{4}$ & $519.23 \pm 54.34^{*}$ & 738.95 & - \\
G3 & $\mathrm{AN}_{1}+\mathrm{CCl}_{4}$ & $190.00 \pm 15.97^{+}$ & 207.00 & 63.41 \\
$\mathrm{G} 4$ & $\mathrm{AN}_{2}+\mathrm{CCl}_{4}$ & $161.30 \pm 59.52^{+}$ & 160.62 & 68.93 \\
G5 & $\mathrm{AN}_{3}+\mathrm{CCl}_{4}$ & $225.40 \pm 50.07$ & 264.19 & 56.96 \\
G6 & $\mathrm{AN}_{4}+\mathrm{CCl}_{4}$ & $226.40 \pm 51.01^{*}$ & 265.81 & 56.91 \\
G7 & $\mathrm{AN}_{5}+\mathrm{CCl} 4$ & $327.54 \pm 65.60^{*}$ & 425.23 & 36.92 \\
\hline
\end{tabular}

ALT activity values are expressed as mean $\pm S D$ of seven rats per group.

*Significantly different from the control value $(P<0.01)$

${ }^{+}$Significantly different from the $\mathrm{CCl}_{4}$ - treated $(G 2)$ value $(P<0.01)$

$A N_{1}-A N_{5}$ represents the various fractions of the anthocyanin extracts:

$A N_{1}$ : Crude (slimmy red) extract

$A N_{2}:$ Lead precipitated (non - slimmy red) extract

$A N_{3}: 12 \times 3.5 \mathrm{~cm}$ Sephadex G-50 column fraction.

$A N_{4}: 50 \times 10 \mathrm{~cm}$ Sephadex $G-50$ column (single red pigment) first fraction.

$A N_{5}: 50 \times 10 \mathrm{~cm}$ Sephadex G-50 column (blue-violet pigment) second fraction.

Table 2: Mean Liver: Body weight gain Ratio

\begin{tabular}{lllllll}
\hline Group & Treatment & $\begin{array}{l}\text { Liver } \\
\text { weight }(\mathbf{g})\end{array}$ & $\begin{array}{l}\text { Initial body } \\
\text { weight }(\mathbf{g})\end{array}$ & $\begin{array}{l}\text { Final body } \\
\text { weight }(\mathrm{g})\end{array}$ & $\begin{array}{l}\text { Weight } \\
\text { gained (g) }\end{array}$ & $\begin{array}{l}\text { Liver: Body } \\
\text { weight gain } \\
\text { ratio }\end{array}$ \\
\hline $\mathrm{G} 1$ & $\mathrm{Control}$ & $3.44 \pm 0.99$ & $156.00 \pm 21.92$ & $175.00 \pm 12.91$ & 19 & 0.1811 \\
$\mathrm{G} 2$ & $\mathrm{CCl}_{4}$ & $4.42 \pm 0.34$ & $165.50 \pm 1.59$ & $165.50 \pm 1.41$ & $0.5^{+}$ & $8.8400^{*}$ \\
$\mathrm{G} 3$ & $\mathrm{AN}_{1}+\mathrm{CCl}_{4}$ & $3.76 \pm 0.99$ & $149.30 \pm 10.73$ & $173.10 \pm 9.04^{+}$ & 23.8 & 0.1580 \\
$\mathrm{G} 4$ & $\mathrm{AN}_{2}+\mathrm{CCl}_{4}$ & $3.59 \pm 0.14$ & $162.50 \pm 18.65$ & $189.00 \pm 13.25$ & 20.5 & 0.1751 \\
$\mathrm{G} 5$ & $\mathrm{AN}_{3}+\mathrm{CCl}_{4}$ & $3.77 \pm 0.23$ & $136.00 \pm 47.71$ & $176.20 \pm 26.65$ & $40.2^{*}$ & $0.0938^{+}$ \\
$\mathrm{G} 6$ & $\mathrm{AN}_{4}+\mathrm{CCl}_{4}$ & $4.03 \pm 0.22$ & $154.00 \pm 4.42$ & $181.70 \pm 5.13$ & 27.7 & 0.1455 \\
$\mathrm{G} 7$ & $\mathrm{AN}_{5}+\mathrm{CCl} 4$ & $3.82 \pm 0.91$ & $155.80 \pm 7.79$ & $188.90 \pm 5.44^{*}$ & 33.1 & $0.0202^{+}$ \\
\hline
\end{tabular}

Weight values are expressed as mean $\pm S D$ of seven rats per group.

* Significantly $(P<0.01)$ higher than the control value.

${ }^{+}$Significantly $(P<0.01)$ lower than the control value.

This large increase suggests hepatic injury. However, rats that were challenged by the anthocyanin extracts had between 160-425\% increments in ALT activity value, an evidence of a measure of hepatoprotection. The lead precipitated extract $\left(\mathrm{AN}_{2}\right)$ possessed the highest degree of protection and the $50 \times 10 \mathrm{~cm}$ Sephadex G-50 column second extract $\left(\mathrm{AN}_{5}\right)$ the lowest, as judged by their ALT values.

Table 2 shows the liver weight: body weight gain ratio. The group of rats challenged with
$12 \times 3.5 \mathrm{~cm}$ Sephadex G-50 column fraction $\left(\mathrm{AN}_{3}\right)$ gained the highest weight followed by the group given the $50 \times 10 \mathrm{~cm}$ Sephadex G-50 column second fraction $\left(\mathrm{AN}_{5}\right)$. The liver weight: body weight gain ratio for the $\mathrm{CCL}_{4}$ treated group had the highest value, indicating that $\mathrm{CCL}_{4}$ increased liver weight - an evidence of inflammation, with very minimal gain in body weight. The liver weight: body weight gain ratio for the rats that received 
$\mathrm{AN}_{2}$ compares well with the control value. $\mathrm{AN}_{2}$ extract appears to have the highest potential of protecting the liver against $\mathrm{CCL}_{4}-$ induced toxicity.

\section{DISCUSSION}

Measurement of plasma ALT activity value has been used as an index of acute liver damage induced by $\mathrm{CCl}_{4}$ exposure. Koji, et $a l{ }^{6}$ observed a significant $(\mathrm{P}<0.01)$ increase in serum ALT activity value (from $37 \mathrm{IU} / \mathrm{L}$ to $553 \mathrm{IU} / \mathrm{L}$ ), 24 hours after administration (subcutaneous injection) of $0.6 \mathrm{ml} / \mathrm{kg}$ body weight of a mixture of carbon-tetrachloride $\left(\mathrm{CCl}_{4}\right)$ in olive oil $(1: 1 \mathrm{v} / \mathrm{v})$ to $12-$ hours fasted rats. They attributed such outrageous increase to acute liver damage occasioned by $\mathrm{CCl}_{4}$ toxicity. In this present study, the significant $(\mathrm{P}<0.01)$ increase $(738.95 \%)$ in ALT activity value $(519.23 \mathrm{IU} / \mathrm{L})$ for the $\mathrm{CCl}_{4}$-treated rats (Table 1) further confirms the hepatotoxic potential of $\mathrm{CCl}_{4}$. But, pre-treatment with anthocyanin extracts reduced the significant increase in plasma ALT activity induced by CCl4 administration. However, the various fractions of the anthocyanin extract differ in their ability to protect the liver from $\mathrm{CCl} 4$ acute damage as evidenced by the ALT activity values (Table 1). The AN2-lead precipitated, non-slimmy red extract possessed the greatest protective property, while AN5 - the sephadex second fraction, showed the least protecting ability. Similarly, Ficus carica leaf extract has been observed to possess a measure of hepatoprotective activity against carbon tetrachloride-induced hepatotoxicity in rats9.

The liver: body weight gain ratio for the CCl4-treated group was statistically demonstrated to be the highest $(\mathrm{P}<0.01)$, suggesting that $\mathrm{CCl} 4$ toxicity increased liver weight (size) but significantly reduced the gain in body weight by mechanism(s) that have not been clearly established.

Carbon tetrachloride could damage the liver via injuries caused by free radical $(\cdot \mathrm{CCl} 3)$ mediated lipid peroxidation10. From the available data, it appears that the lead precipitated, non-slimmy red extract of anthocyanin, AN2 possesses the highest antioxidant potential. The AN2 fraction should be characterized and studied for its potent antioxidant property against acute liver damage caused especially by $\mathrm{CCl} 4$ and allied substance(s).

\section{REFERENCES}

1. Reinke LA, Lai EK, McCay PB. Ethanol feeding stimulates trichloromethyl radical formation from carbontetrachloride in liver. Xenobiotica 1988; 18 : $1311-1318$.

2. Aruoma IO. Free radicals and antioxidant strategies in sports. J Nutr Biochem. 1994; 5:370 - 381.

3. Tatsuzawa F, Saito N, Yokoi M et al. An acylated cyanidin glycoside in the red - purple flowers of $X$. Laeliocattleya CV mini purple . Phytochemistry, 1994; 37: $1179-1183$

4. Marcelo F, Eduarodo L, Reme T et al. Antioxidant activities of lignans and flavonoids. Phytochemistry, 1990; 29: 3773 - 3775.

5. Kosaku T, Sjuju S, Hiromitsu $\mathrm{K}$ et al. The anthocyanin responsible for purpish blue flower colour of Aconitum Chinese. Phytochemistry, 1994; 36(3): $613-616$

6. Koji H, Shigetoshi K, Purusotam B et al. Hepatoprotective effects of the active constituent from seeds of Celosia argenta. Phytotherap Res.1996; 10: $387-393$.

7. Reitman S, Frankel S. A colorimetric method for the determination of serum glutamic oxaloacetate and glutamic pyruvic transaminases. Am J Clin Pathol. 1957; $28: 56-62$.

8. Winer BJ, Brown DR, Michels M. Design and analysis of single-factor experiment : Completely randomized design. In: Statistical Principles in Experimental Design. New York : McGraw Hill Inc., 1991; pp 74-418.

9. Mohan GK, Pallavi E, Ravikumar B et al. Hepatoprotective activity of Ficus carica Linn leaf extract against carbon tetrachloride-induced hepatotoxicity in rats. $D A R U, 2007$; 15(3): 162-166.

10. Brattin WJ, Glende EA (Jr), Recknagel RO. Pathological mechanisms in carbontetrachloride hepatotoxicity. J Free Radic Biol Med. 1985; 1:27 28. 